6-1-2013

\title{
Evaluating Tablet Technology in an Undergraduate Nursing Program
}

\author{
Beth Ann Swan \\ Thomas Jefferson University \\ Kellie Smith \\ Thomas Jefferson University \\ Anthony J. Frisby \\ Thomas Jefferson University \\ Kathryn Shaffer \\ Thomas Jefferson University \\ Mary Hanson-Zalot \\ Thomas Jefferson University \\ Follow this and additional works at: https://jdc.jefferson.edu/nursfp \\ Part of the Nursing Commons

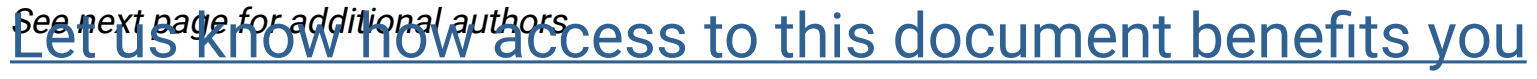

\section{Recommended Citation}

Swan, Beth Ann; Smith, Kellie; Frisby, Anthony J.; Shaffer, Kathryn; Hanson-Zalot, Mary; and Becker, Julie, "Evaluating Tablet Technology in an Undergraduate Nursing Program" (2013). College of Nursing Faculty Papers \& Presentations. Paper 65.

https://jdc.jefferson.edu/nursfp/65

This Article is brought to you for free and open access by the Jefferson Digital Commons. The Jefferson Digital Commons is a service of Thomas Jefferson University's Center for Teaching and Learning (CTL). The Commons is a showcase for Jefferson books and journals, peer-reviewed scholarly publications, unique historical collections from the University archives, and teaching tools. The Jefferson Digital Commons allows researchers and interested readers anywhere in the world to learn about and keep up to date with Jefferson scholarship. This article has been accepted for inclusion in College of Nursing Faculty Papers \& Presentations by an authorized administrator of the Jefferson Digital Commons. For more information, please contact: JeffersonDigitalCommons@jefferson.edu. 


\section{Authors}

Beth Ann Swan, Kellie Smith, Anthony J. Frisby, Kathryn Shaffer, Mary Hanson-Zalot, and Julie Becker 


\section{Evaluating Tablet Technology in an Undergraduate Nursing Program}

BETH ANN SWAN, KELLIE A. SMITH, ANTHONY FRISBY, KATHRYN SHAFFER, MARY HANSON-ZALOT, AND JULIE BECKER

w

ith the introduction of tablet technology, faculty began asking questions about when, where, and how tablets might enhance curriculum opportunities for student learning and faculty teaching strategies beyond their use as personal digital devices and smart phones (Swan, Smith, Frisby, Shaffer, \& Hanson-Zalot, 20I2). Personal digital devices (PDDs), including smart phones, had been used by nursing students for the past five years. The purpose of this study was to evaluate how tablet technology affected student and faculty teaching-learning processes and outcomes in an accelerated, pre-licensure baccalaureate nursing program.

Following four months of planning, we integrated tablets into classroom teaching, simulation/laboratory sessions, and clinical experiences. With institutional review board approval, the researchers employed a qualitative descriptive design, using focus groups, to elicit data from students and faculty. Four focus groups were conducted, one with faculty and three with students. Eight faculty attended the session, representing 40 percent participation; 14 students attended the three sessions, representing 11 percent participation. Participants were asked about their experiences with tablets, concerns about implementation, and recommendations.

Overall, there were surprising congruencies between faculty and students, especially in the area of using the tablet for classroom use. Although many in the four groups expressed a "cool" and "wow" reaction, the availability of appropriate software and limitations in the use of the technology influenced the experience of students and faculty.

Experiences with the Tablets Most faculty had little previous experience with PDDs. Most students had experience with iTunes, and several had experience with Apple computers or iPhones; most were familiar with applications (apps) and how to use the iTunes store. This familiarity was not sufficient to overcome some of the most complicated aspects of the tablet software and app installations.

Faculty received their tablets (Apple iPad2) approximately four weeks before classes started; all faculty agreed that this was not enough time to prepare for class, despite technical and instructional design support. Students also felt unprepared for the use of tablets; several reported "feeling lost" and sought out campus technical support. Of note, an instruction manual and one-onone student and faculty sessions, as well as group sessions with technical and instructional design staff were offered frequently, but few students and faculty participated.

Like faculty, students wanted time to learn more about the tablets before being required to use them. Students and faculty turned to peers who were "super users" for help with applications and software issues. While they found this additional assistance helpful, their need for technical support was not satisfied.

Faculty noted they needed instruction on how to incorporate the technology into lesson plans, classroom activities, simulations, and clinicals. They thought more time and instruction would have helped with integration of the tablet into their teaching. Students commented that there was a disconnect between what instructors had in the syllabus or talked about in class and what was available on the tablet, specifically readings (chapters and page numbers) or the need to download additional apps.

Faculty thought the tablet supported the integration of different teaching strategies with classroom content, yet several faculty stated they had not received sufficient training or had not made the time to adapt course content. Students had a different perception of the tablet in the classroom. The device offered too many opportunities to multitask, including checking email and Facebook. The students also noted that some faculty were facile with the device and integrated materials well into the classroom settings while others grossly underutilized the technology. All students liked having the ability to take notes using the Notarize or Evernote apps, and some commented that they liked the ability to record lectures.

The idea of individualized learning styles came up in two of the three student focus groups. Several of the students commented that their personal learning styles were supported by the tablet; others stated that they needed to physically write on a surface in order to master the materials.

The use of tablets in clinical settings proved most complicated. Faculty said the device was met with resistance by practicing clinicians; many sites did not permit their use on hospital floors due to privacy concerns, and certain areas had no Internet connection (WiFi). Discussions have since been initiated with hospital representatives regarding the competing requirements of practice and education. Nurses in the clinical setting did not see an immediate use for the device in their settings, but faculty are working with them to identify areas for common use. For example, a unit-based clinical expert was brought into the classroom via FaceTime.

Students were required to purchase a lab coat with a pocket designed to carry the tablet, but the oversized protective covers that 
several students purchased did not fit into these lab coats. One student designed a pouch that matched the school uniform for carrying her tablet. All students commented that there was no place to leave the device safely within the hospital.

Faculty and several students "loved" the convenience of having an electronic calendar. The students agreed almost unanimously that Nursing Central ${ }^{\mathrm{TM}}$, especially the pharmaceutical information, was the most useful component of the electronic textbooks. All felt tablets were good for reviewing class notes or videos when commuting to and from school, as long as other commuters were shielded from potentially disturbing images. Most of the students liked the ease of having all their textbooks in one easy-to-carry device, yet several felt there were significant problems with the tablet version of the textbooks used: a) the backlit screen made reading difficult and contributed to eye strain; b) bookmarking was unavailable within the textbooks; c) tables and illustrations were spread across multiple pages, making them hard to follow and unrelated to the content on the page; d) pagination did not match the printed textbooks; and e) the instructors' readings were designed for printed textbooks, not for the e-books. In addition to the expense of purchasing the tablet, several students acquired print versions of the textbooks as well, because they felt their learning styles benefitted from printed books. Students asserted that these books were easier to follow, and tables and illustrations matched the text better.

Concerns About Implementation Several concerns about implementation were similar for faculty and students. Both groups agreed they did not have enough time to learn how to incorporate the tablet into their personal learning strategies. Faculty suggested that they needed at least four more weeks to integrate tablet information into their courses, simulations, and clinical rotations. Students thought they would need two to four weeks prior to beginning their course work. To gain comfort with the device, both groups agreed they needed additional technical support from the institution and an ongoing way to share information and issues. A discussion board was created at the beginning of this pilot for students to use for sharing information.

Several students stated the technology was "too new," with insufficient software and applications for the program's accelerated learning goals. The tablet and its related issues were a "stressor" that students felt they did not need.

Faculty and students expressed concerns about test taking on the tablet. Although no one directly stated that cheating had occurred, faculty and students alluded to the potential for cheating. Students reported being "kicked out" of the tests while taking them online, losing the Internet connection during the test or when they were ready to submit the completed examination. Several said this caused significant stress and anxiety. Faculty and students spoke of the tablets allowing students to look up materials in reference books, articles, and videos while taking a test, but faculty felt that hunting for answers would be obvious to proctors and take too much time.

Recommendations for Future Use Faculty acknowledged that the future of nursing education should include the use of tablets. Students concurred, but were conflicted about whether the use of tablets should be required. They felt applications specific for nursing were not readily available and again mentioned the limitations in technical support that was provided by the various clinical institutions and the wide variability in skill level on the part of instructors. Faculty believed their skills would change rapidly as they became more comfortable with the technology and experienced in developing learning materials.

The students were very enthusiastic about using tablets for patient education in the clinical settings that allowed them. Several students who had used their tablets in this way thought patient education was its greatest potential.

Going Forward Since the pilot study, the school has expanded the use of tablet technology, incorporating tablets into the prelicensure baccalaureate program. Based on findings from the pilot program, targeted improvements have been made to both technical and instructional design support systems. Faculty and student user manuals have been revised, and technology orientation sessions have been streamlined, with educational sessions specifically for faculty new to the initiative. A new text vendor has provided a more user-friendly interface with simplified features for note taking, highlighting, and bookmarking. It is anticipated that expansion of tablet technology within the nursing curriculum will prompt an array of innovative teaching-learning strategies for both faculty and students.

About the Authors Five of the authors are faculty at Thomas Jefferson University Jefferson School of Nursing, Philadelphia, Pennsylvania. Beth Ann Swan, PhD, CRNP, FAAN, is dean and professor. Kellie A. Smith, EdD, RN, is an assistant professor. Anthony Frisby, PhD, is an associate professor. Kathryn Shaffer, MSN, RN, CNE, and Mary Hanson-Zalot, MSN, RN, are instructors. Julie Becker, PhD, is an evaluation consultant, Newark, New Jersey. For more information, contact Dr. Swan at bethannswan@gmail.com.

\section{Reference}

Swan, B. A., Smith, K., Frisby, A., Shaffer, K., \& Hanson-Zalot, M. (20I2). A teaching-learning initiative with tablet computing. Computers, Informatics, Nursing, 30(9), 449-453. 